\title{
Physical Characteristics of Mature Green and Ripe Tomato Fruit Tissue of Normal and Firm Genotypes
}

\author{
E.V. Wann ${ }^{1}$ \\ U.S. Department of Agriculture, Agricultural Research Service, South Central Agricultural Research \\ Laboratory, P. O. Box 159, Highway 3 West, Lane, OK 74555
}

Additional index words. Lycopersicon esculentum Mill., fruit firmness, tomato quality, elasticity, fruit softening, tissue strength, tissue texture

\begin{abstract}
Tissue firmness of ripe tomatoes is controlled by cell wall integrity of the fruit tissue and by the enzymatic softening that normally occurs during ripening. This study was conducted to determine the physical characteristics of cells and tissues of mature green (MG) and ripe fruit that might account for differences in firmness between 'Rutgers' (normal), 'Flora-Dade' (Firm), and two mutant lines called high-pigment (T4065 hp) and dark-green (T4099 dg), both of which possess extra firm fruit. Fruit samples were tested for resistance to a force applied to whole fruit and to sections of the pericarp tissue and by stress-relaxation analysis. Determinations were also made of cell density and cell wall content within the pericarp tissue. Fruit of mutant lines had firmer tissue than either 'Rutgers' or 'Flora-Dade' at MG or ripe. Whole fruit compression measurements showed that T4099 $d g$ was firmer than T4065 $h p$ or 'Rutgers' at MG and firmer than 'Flora-Dade' and 'Rutgers' when ripe. Whole fruit of 'Flora-Dade' were significantly firmer than 'Rutgers' at MG and ripe. Firmness measured by compressive strength also showed that mutant lines had firmer pericarp tissue than the wild types at both MG and ripe stages. Stress-relaxation analysis showed that MG fruit of T4099 dg had greater tissue elasticity than 'Rutgers' or 'Flora-Dade'. Ripe fruit of both mutant lines had more tissue elasticity than wild types. There were no apparent differences among the genotypes due to tissue relaxation. From these analyses, tissue elasticity appears to be a significant parameter in determining tissue firmness in the tomato genotypes used in this study. Firmness and textural quality of ripe tomatoes appeared to be dependent on elasticity of the pericarp tissue and on the level of enzymatic softening during ripening.
\end{abstract}

Fruit firmness is an important criterion for determining the marketability of fresh tomatoes because it is associated with good culinary quality and long shelf life. The softening of tomato fruit tissue that normally accompanies ripening has been attributed to cell wall structural modification by hydrolytic enzymes (Buescher et al., 1976; Crookes and Grierson, 1993; Gross, 1990; Gross and Wallner, 1979; Fischer and Bennett, 1991; Richardson and Hobson, 1987; Seymour et al., 1987). There are several tomato genotypes and cultivars that have firmer than normal fruit at the MG stage of maturity, ripen normally, and remain firm when fully ripe (Jarret et al., 1984; Koch and Nevins, 1990; Thompson et al., 1961; Tong and Gross, 1989; Wann et al., 1985). It appears there are several factors contributing to firmness in ripe tomatoes, some of which may be physical in nature and separate from those related to reduced enzymatic softening during the ripening process.

Studies of the physiological characteristics related to the extra firmness observed in the ripe fruit of tomato mutants high-pigment $(h p)$ and dark-green $(d g)$ showed that the mutants had similar or greater endo-polygalacturonase (EC 3.2.1.15), a fruit softening enzyme, activity than normal (Koch and Nevins, 1990; Tong and Gross, 1989, Wann et al., 1985). Total $\beta$-galactosidase (EC 3.2.1.23) and invertase (EC 3.2.1.26) activity was similar, but pectinmethylesterase (EC 3.1.1.11) activity was considerably less in the mutants than in the normal genotype (Koch and Nevins 1990, Wann et al., 1985). Koch and Nevins (1990) found that pectinmethylesterase activity in cell wall protein extracts from ripe

Received for publication 16 Aug. 1995. Accepted for publication 27 Nov. 1995. Technical assistance of R.G. Marble is gratefully acknowledged. Mention of a trademark, vendor or proprietary product does not constitute a guarantee or warranty of the product by the U.S. Department of Agriculture and does not imply its approval to the exclusion of other products that may also be suitable. The cost of publishing this paper was defrayed in part by the payment of page charges. Under postal regulations, this paper therefore must be hereby marked advertisement solely to indicate this fact.

${ }^{1}$ Research geneticist. $d g$ fruit was about half that found in extracts from a standard tomato. They concluded that pectinmethylesterase and polygalacturonase were not active in situ during the ripening of $d g$ fruit, which could account for less softening during the ripening process. Reduced activity by the fruit softening enzymes during ripening, however, does not account for the extra firmness in the mature-green (MG) fruit of the mutant genotypes. Physicochemical characteristics of cell walls in the tissue of mutant types might account for their extra firmness and apparent resistance to enzymatic softening during ripening. Koch and Nevins (1990) found that heat-inactivated cell walls from $d g$ fruit at all ripening stages showed low susceptibility to polygalacturonase compared to the standard tomato cultivar VF145B.

Measurements of ripe fruit firmness in relation to the enzyme activities putatively involved in fruit softening generally do not take into account the carry-over effect of tissue firmness at the MG stage. The extra firmness found in MG fruit of 'Flora-Dade' and the $h p$ and $d g$ genotypes may be attributed to physical characteristics of cell walls and tissues, since softening enzymes are presumed to be absent or inactive at that stage. If true, then differences in ripe fruit firmness between firm-fruited ( $h p$ and $d g$ ) and normal cultivars, such as 'Rutgers', may be attributed in part to differences in physical properties of the tissue that were developed before onset of ripening.

The purpose of this research was to determine some of the physical characteristics of cells and tissues that would account for differences in tomato fruit firmness in $h p, d g$, and normal genotypes. In this study, we considered cell density within the pericarp tissue, cell wall content, and firmness of whole fruit and pericarp tissue.

\section{Materials and Methods}

Near isogenic lines homozygous recessive at the $h p$ or $d g$ loci were developed by backcrossing twice to 'Flora-Dade' with interposed selection for the desired phenotype, followed by five gen- 
erations of inbreeding. The mutant lines, designated T4065 $\mathrm{hp}$ and T4099 $d g$, along with 'Flora-Dade' and 'Rutgers' (wild types) were grown in 8-liter pots filled with a standard greenhouse potting mix. Following set of the first fruit cluster, a soluble fertilizer (20N-20P-20K) was applied at the rate of $5 \mathrm{~g} /$ pot weekly to maintain plant vigor. Four plants per plot were grown in a randomized complete block design with four replications.

Fruit samples were harvested in pairs within a cluster according to maturity at 38 to 44 days postanthesis. One fruit was selected at the turning stage of ripeness and an adjacent fruit at MG, which would be turning in 2 to 4 days. Using this procedure, we were able to minimize fruit size differences between ripe and $\mathrm{MG}$ and to select both ripeness classes from the same relative position on the plant. Fruit size and shape were comparable among the four genotypes. Five to seven fruit at each ripeness were harvested from each plot for analyses. The MG samples were processed immediately, but the turning fruit were tagged and held in the laboratory on open trays at room temperature for 3 to 5 days to complete ripening.

Fruit and tissue firmness measurements. Fruit firmness measurements were made with a TA-XT2 texture analyser (Texture Technologies, Scarsdale, N.Y.). Whole fruit firmness was determined by the peak force reached when fruit were compressed laterally a distance of $5 \mathrm{~mm}$ at the rate of $1 \mathrm{~mm} \cdot \mathrm{sec}^{-1}$. Determinations were made from three equatorial positions on each fruit.

Fruit of MG and ripe samples were cut in half equatorially and the tissue firmness determinations made at the cut surface of the distal (blossom-end) half. Compressive strength of the tissue was measured by determining the amount of force required to collapse a tissue cylinder cut from the MG and ripe pericarp tissue (Jackman and Stanley, 1992). Three tissue cylinders, $0.6 \mathrm{~cm}$ in diameter and $0.5 \mathrm{~cm}$ in length, were cut vertically from the equatorial region of each fruit with a cork borer. Care was taken to avoid vascular bundles since they tend to have greater resistance to compression than adjacent tissue

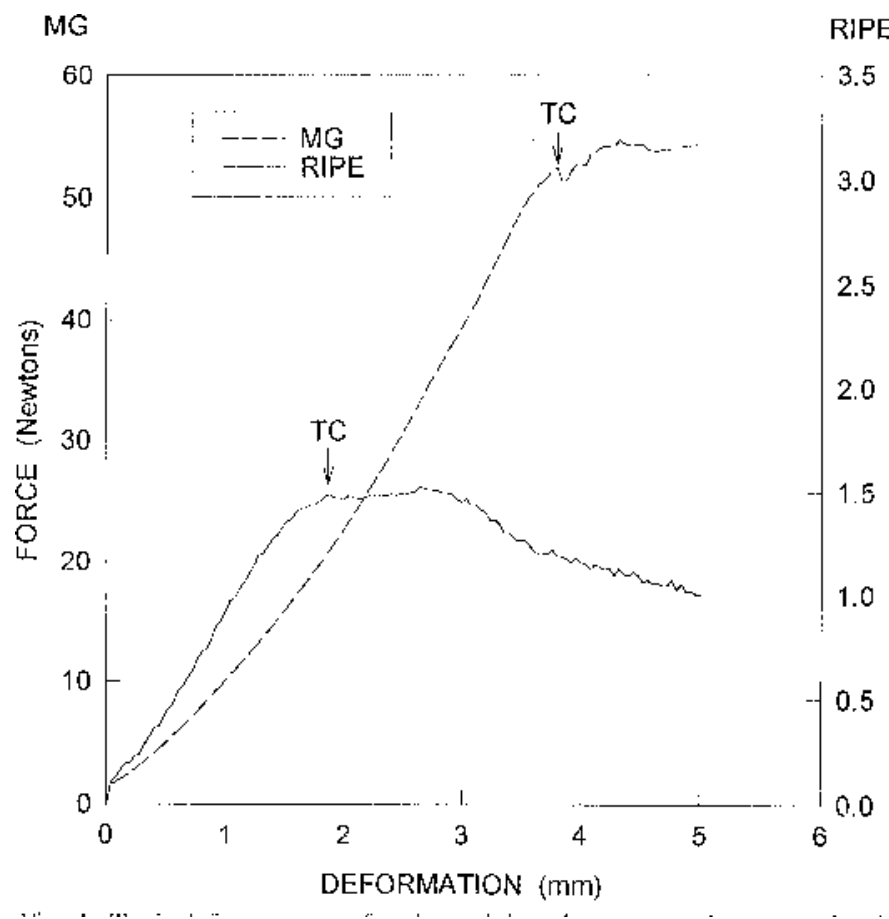

Fig. 1. Typical force curves for determining the compressive strength of a cylinder of MG and ripe 'Flora-Dade' tomato fruit tissue $6 \mathrm{~mm}$ in diameter and $5 \mathrm{~mm}$ in length. Cylinders were compressed end to end with a TX-XT2 texture analyzer at the rate of $1 \mathrm{~mm} \cdot \mathrm{s}^{-1}$. Tissue strength is indicated by the force (Newtons) being exerted at the point of tissue collapse (TC), indicated by an arrow on each curve. (data not shown). Each cylinder was compressed end to end at the rate of $1 \mathrm{~mm} \cdot \mathrm{s}^{-1}$ until the tissue collapsed. The peak force applied at the point of tissue collapse was recorded. The TA-XT2 texture analyser also produced a force-deformation curve for each cylinder typical of that shown in Fig. 1.

Stress-relaxation analysis was performed according to the procedures described by Kojima et al. (1991) and Sakurai and Nevins (1992), with some modifications, to determine the viscoelastic properties of the pericarp tissue. The TA-XT2 texture analyser was programmed to insert a conical probe into the pericarp tissue $0.6 \mathrm{~mm}$ and hold static for $60 \mathrm{sec}$ while load decay (relaxation) was recorded at 0.17 -sec intervals. The initial load $\left(\mathrm{L}_{\mathrm{i}}\right)$ was the peak force recorded when the probe reached a $0.6-\mathrm{mm}$ depth, and the residual load $\left(\mathrm{L}_{\mathrm{r}}\right)$ was the residual force after $60 \mathrm{sec}$ of decay. Separate tests were made at three positions on the cut surface of the pericarp tissue and averaged for a single set of values for each fruit. Rate of load decay (R) was calculated for $60 \mathrm{sec}(\mathrm{t})$ following the time at which the initial load was achieved, using the equation $\mathrm{R}=\mathrm{L}_{\mathrm{i}}-\mathrm{L}_{\mathrm{r}} / \mathrm{t}$.

According to Sakurai and Nevins (1992), stress-relaxation analysis assumes that $\mathrm{L}_{\mathrm{i}}$ represents the elastic properties of the tissue, and load decay is determined by the viscosity of the cell walls. Therefore, $\mathrm{L}_{\mathrm{i}}$ and $\mathrm{R}$ represent separate physical parameters of tissue firmness. Analysis of variance was performed on each of the data sets to determine differences among genotypes for $\mathrm{L}_{\mathrm{i}}$.

Tissue observations and cell wall extraction. All pericarp tissue was excised from each fruit, and a thin cross-section was cut from the pericarp of a representative fruit of both stages of ripeness in each plot. Each specimen was placed in a separate vial with a mixture of ETOH : formalin : acetic acid : $\mathrm{H}_{2} \mathrm{O}(10: 2: 1: 7, \mathrm{v} / \mathrm{v} / \mathrm{v} / \mathrm{v})$ and subsequently processed for scanning electron microscopy (SEM). The remaining pericarp tissue was combined into one sample for each ripeness stage in each plot. About $100 \mathrm{~g}$ of the combined pericarp tissue was dried in a convection oven at $90 \mathrm{C}$ to complete dryness from which dry weight was determined. The remainder of the combined pericarp tissue was frozen at-10C and used for cell wall analysis.

Cell walls were extracted from peeled pericarp tissue using procedures described by Gross (1984) and Tong and Gross (1989), with slight modifications. One hundred grams of frozen pericarp were peeled and homogenized in $200 \mathrm{ml}$ of $80 \%$ ethanol with a polytron homogenizer (Brinkmann Instruments, Westbury, N.Y.) and subjected to a sonic dismenbrator (Fisher Scientific, Pittsburgh, Pa.) for $1 \mathrm{~min}$. The solution was filtered through Miracloth (Calbiochem) and the residue suspended in $200 \mathrm{ml}$ of $20 \mathrm{mM}$

Table 1. Force measurements (Newtons) of whole-fruit firmness and pericarp tissue collapse in mature green (MG) and ripe fruit of mutant and normal tomato genotypes.

\begin{tabular}{lccrrr}
\hline \hline & \multicolumn{2}{c}{$\begin{array}{c}\text { Whole fruit } \\
\text { firmness }^{\mathrm{z}}\end{array}$} & & \multicolumn{2}{c}{$\begin{array}{c}\text { Tissue collapse } \\
\text { force }^{\mathrm{y}}\end{array}$} \\
\cline { 2 - 3 } \cline { 5 - 6 } Genotype & MG & Ripe & & MG & Ripe \\
\hline T4099 $d g$ & 76.5 & 24.5 & & 63.7 & 7.6 \\
T4065 hp & 63.7 & 21.6 & & 63.4 & 3.5 \\
Flora-Dade & 71.6 & 20.6 & & 55.9 & 1.5 \\
Rutgers & 55.9 & 16.7 & & 55.1 & 0.8 \\
LSD $(P \leq 0.05)$ & 9.8 & 2.9 & & 4.6 & 1.0
\end{tabular}

${ }^{\mathrm{z}}$ Force exerted when whole tomato fruit were compressed laterally $0.5 \mathrm{~mm}$ at the rate of $1 \mathrm{~mm} \cdot \mathrm{s}^{-1}$.

y Force exerted to produce cellular collapse in a tissue cylinder $0.6 \mathrm{~cm}$ in diameter and $0.5 \mathrm{~cm}$ in length, cut from the tomato fruit pericarp and compressed lengthwise. 
HEPES-NaOH buffer ( $\mathrm{pH}$ 7.6) and homogenized for 1 min. The homogenate was filtered through Miracloth and washed with excess HEPES buffer. The residue was resuspended in $150 \mathrm{ml}$ of the HEPES buffer to which about 48000 units of $\alpha$-amylase (EC 3.2.1.1; Sigma \#A6255) were added. One drop of toluene was added and the sample incubated at $30 \mathrm{C}$ for $18 \mathrm{~h}$ on a shaker. The suspension was filtered and washed with excess buffer. The residue was resuspended in $200 \mathrm{ml}$ of 1 chloroform: 1 methanol (v/v), homogenized, filtered, rinsed with excess chloroform : methanol, and washed with acetone. Cell walls were dried in a vacuum oven at $35 \mathrm{C}$ for $72 \mathrm{~h}$. Cell wall content was recorded as mg of cell wall material per $\mathrm{g}$ of tissue dry weight. Data were subjected to analysis of variance using SAS (SAS, Cary, N.C.) and differences among means were identified by least significant difference (LSD, $P \leq 0.05$ ).

\section{Results and Discussion}

There were significant differences among the four genotypes for whole fruit and tissue firmness at the MG stage of maturity (Table 1). Similar firmness differences were also evident in the ripened fruit, but the degree of firmness was greatly reduced (Table 1). Firmness measurements of whole fruit showed that T4099 $d g$ had firmer fruit than 'Rutgers' or T4065 $\mathrm{hp}$ at MG and firmer than 'Rutgers' and 'Flora-Dade' when ripe (Table 1). The same general relationship existed among genotypes for ripe whole-fruit firmness as for MG, although ripe fruit of all genotypes were much softer than MG (Table 1).

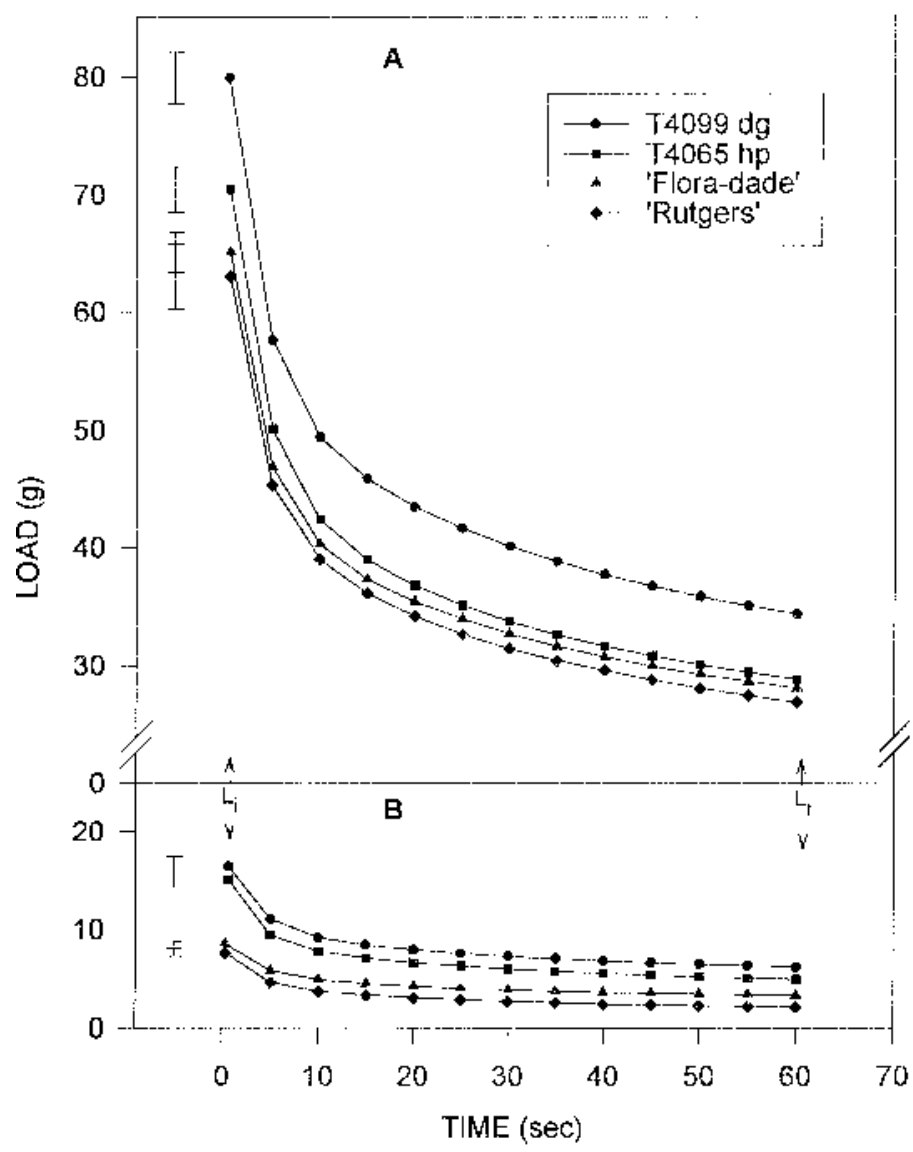

Fig. 2. Stress-relaxation analysis of $\mathrm{MG}(\mathbf{A})$ and ripe $(\mathbf{B})$ tomato fruit pericarp tissue. Initial load force $\left(\mathrm{L}_{\mathrm{i}}\right)$ is shown at time 0 followed by load decay (relaxation) and residual load force $\mathrm{L}_{\mathrm{r}}$ ) at $60 \mathrm{sec}$. Load decay was recorded at 0.17 -sec intervals while the probe was static. Bars shown at the left of $\mathrm{L}_{\mathrm{i}}$ values represent $\mathrm{SE}$ at $\mathrm{n}=$ 24 for $\mathrm{L}_{\mathrm{i}}$ only.
Determining the force required to cause tissue collapse provided a sensitive method for measuring tissue firmness in both MG and ripe fruit. The force at which tissue cylinders collapsed (tissue failure) was readily discernable with the TA-XT2 texture analyser as shown in Fig. 1. Both MG and ripe fruit tissue from genotypes $\mathrm{T} 4099 d g$ and $\mathrm{T} 4065 \mathrm{hp}$ showed significantly greater resistance to tissue collapse than 'Flora-Dade' or 'Rutgers' Table 1. Compressive strength of the ripe tissue cylinders from T4099 $d g$ and T4065 $h p$ was $6 \%$ to $12 \%$ of that of comparable MG tissue cylinders, while that of 'Flora-Dade' and 'Rutgers' was only $2 \%$ to $4 \%$, indicating a more active softening process in the latter genotypes.

Stress-relaxation analyses on the MG and ripe fruit of the four genotypes are shown in Fig. 2. $\mathrm{L}_{\mathrm{i}}$ values for MG tissue were greater for genotype T4099 $d g$ than for the other genotypes. $\mathrm{L}_{\mathrm{i}}$ values for T4065 $h p$ and 'Flora-Dade' were not significantly different, but both were greater than those for 'Rutgers'. According to Sakurai and Nevins (1992) these parameters represent elastic properties of the tissue. There were no significant differences in $\mathrm{L}_{\mathrm{i}}$ of ripe tissue cylinders between T4065 $h p$ and T4099 $d g$ or between 'FloraDade' and 'Rutgers' (Fig. 2). The same general relationship existed among genotypes for stress-relaxation analysis of ripe and MG tissue, but at much reduced load levels in the ripe.

Load decay was detected immediately after the probe was stopped at the $0.6 \mathrm{~mm}$ depth of penetration (Fig. 2). About $50 \%$ of the initial load recorded for $\mathrm{MG}$ and ripe tissue of all genotypes decayed within the first $30 \mathrm{sec}$. Decay beyond $60 \mathrm{sec}$ in all genotypes, $\mathrm{MG}$ or ripe, was $<0.1 \mathrm{~g} \cdot \mathrm{s}^{-1}$ (data not shown). It is likely that some of the low level decay beyond $60 \mathrm{sec}$ was due to evaporation of moisture from the exposed surface of the tissue, although that was not measured in the present study. Therefore, projection of the decay curve beyond $60 \mathrm{sec}$ could lead to an erroneous interpretation of load decay. The $\mathrm{R}$ values for decay in both $\mathrm{MG}$ and ripe tissue were obviously influenced by $\mathrm{L}_{\mathrm{i}}$, eg., the higher the $\mathrm{L}_{\mathrm{i}}$, the greater the $\mathrm{R}$ values. However, load decay $\left(\mathrm{L}_{\mathrm{i}}-\right.$ $\mathrm{L}_{\mathrm{r}}$ ) expressed as a percent of the initial load was nearly identical for the four genotypes (data not shown). These results indicated that differences in tissue firmness in both $\mathrm{MG}$ and ripe fruit were related to $L_{i}$ values. Differences in tissue firmness among the genotypes used in these studies did not appear to be related to the amount or rate of load decay, suggesting that cell wall viscosity was not a determining factor for differences in fruit firmness.

Cellular differences were detected in measurements of cell density in ripe tissue and cell wall content of MG pericarp tissue (Table 2). However, there were no differences between genotypes for cell density in pericarp tissue of MG fruit. Cell density in ripe fruit showed T4099 $d g$ to have the highest cell density, followed

Table 2. Cell density and cell wall content in pericarp tissue of mature green (MG) and ripe fruit of mutant and normal tomato genotypes.

\begin{tabular}{lccccc}
\hline \hline & \multicolumn{2}{c}{$\begin{array}{c}\text { Cell density } \\
\left(\text { cells } / \mathrm{cm}^{3}\right)\end{array}$} & & \multicolumn{2}{c}{$\begin{array}{c}\text { Cell wall content } \\
\left(\mathrm{mg} \cdot \mathrm{g}^{-1}\right.\end{array}$} \\
\cline { 2 - 3 } \cline { 5 - 6 } dry & & & MG $)$ \\
\hline Tenotype & MG & Ripe & & 137.2 & Ripe \\
\hline T4099 $d g$ & 224 & 198 & & 125.9 & 38.5 \\
Flo65 $h p$ & 219 & 172 & & 129.8 & 36.8 \\
Rutgers & 227 & 151 & & 75.7 & 33.6 \\
LSD $(P \leq 0.05)$ & 222 & 136 & & 21.4 & NS
\end{tabular}

${ }^{\mathrm{z}}$ Cell density was calculated from cell counts made on electron micrographs $(\mathrm{SEM})$ at $10 \times$ magnification for each genotype and ripeness. ${ }^{\mathrm{y} C e l l}$ walls were extracted from $100 \mathrm{~g}$ of fresh pericarp tissue, dried in a vacuum oven at $35 \mathrm{C}$ for $72 \mathrm{~h}$ and weighed. Data are shown as $\mathrm{mg} \cdot \mathrm{g}^{-1}$ of tissue dry weight. 
by T4065 hp, 'Flora-Dade' and 'Rutgers' (Table 2). 'Rutgers' yielded less cell wall material from MG fruit than the other genotypes, but there were no differences for ripe fruit (Table 2). No structural differences in cell walls were visible in the EMC photomicrographs of each of the four genotypes (not shown). However, considerable pericarp cell separation was evident in ripe 'Rutgers' fruit and to a lesser extent in 'Flora-Dade'. None was evident in T4099 $d g$ or T4065 hp. These observations suggested that durable middle lamella and rigid cell cohesion are essential for ripe tissue firmness, which would likely show a positive effect on elasticity of the tissue.

The nature of firmness in MG tissue appeared to be related to tissue integrity or cell wall makeup that is characteristic of each genotype. The relative firmness of $\mathrm{MG}$ fruit persisted during ripening and had a positive effect on firmness of ripe fruit. Further analyses of cell wall structure and cellular cohesion within the tissue will be necessary to determine the physicochemical basis for inherent differences in tomato fruit firmness.

\section{Literature Cited}

Buescher, R.W., W.A. Sistrunk, E.C. Tigchelaar, and T.J. Ng. 1976. Softening, pectolytic activity, and storage-life of rin and nor tomato hybrids. HortScience 11:603-605.

Crookes, P.R. and D. Grierson. 1993. Ultrastructure of tomato fruit ripening and the role of polygalacturonase isoenzymes in cell wall degradation. Plant Physiol. 72:1088-1093.

Fischer, R.L. and A.B. Bennett. 1991. Role of cell wall hydrolases in fruit ripening. Annu. Rev. Plant Physiol. Plant Mol. Biol. 42:675-703.

Gross, K.C. 1984. Fractionation and partial characterization of cell walls from normal and non-ripening tomato fruit. Physiol. Plant. 62:25-32.
Gross, K.C. 1990. Recent developments on tomato fruit softening. Postharvest News Info. 1:109-112.

Gross, K.C. and S.J. Wallner. 1979. Degradation of cell wall polysaccharides during tomato fruit ripening. Plant Physiol. 63:117-120.

Jackman, R.L. and D.W. Stanley. 1992. Area- and perimeter-dependent properties and failure of mature-green and red-ripe tomato pericarp tissue. J. Tex. Stud. 23: 461-474.

Jarret, R.L., H. Sayama, and E.C. Tigchelaar. 1984. Pleiotropic effects associated with the chlorophyll intensifier mutations high pigment and dark green in tomato. J. Amer. Soc. Hort. Sci. 109:873-878.

Koch, J.L. and D.J. Nevins. 1990. The tomato fruit cell wall. II. Polyuronide metabolism in a nonsoftening tomato mutant. Plant Physiol. 92:642647.

Kojima, K., N. Sakurai, S. Kuraishi, R. Yamamoto, and D.J. Nevins. 1991. Novel technique for measuring tissue firmness within tomato (Lycopersicon esculentum Mill.) fruit. Plant Physiol. 96:545-550.

Richardson, C. and G.E. Hobson. 1987. Compositional changes in normal and mutant tomato fruit during ripening and storage. J. Sci. Food Agr. 40:245-252.

Sakurai, N. and D.J. Nevins. 1992. Evaluation of stress-relaxation in fruit tissue. HortTechnology 2:398-402.

Seymour, G.B., S.E. Harding, A.J. Taylor, G.E.Hobson, and G.A. Tucker. 1987. Polyuronide solubilization during ripening of normal and mutant tomato fruit. Phytochemistry 26:1871-1875.

Thompson, A.E. 1961. A comparison of fruit quality constituents of normal and high pigment tomatoes. Proc. Amer. Soc. Hort. Sci. 78:464473.

Tong, C.B.S. and K.C. Gross. 1989. Ripening characteristics of a tomato mutant dark green. J. Amer. Soc. Hort. Sci. 114: 635-638.

Wann, E.V., E.L. Jourdain, R. Pressey, and B.G. Lyon. 1985. Effect of mutant genotypes $h p o g^{c}$ and $d g \sigma^{c}$ on tomato fruit quality. J. Amer. Soc. Hort. Sci. 110:212-215. 